\title{
Tobacco and Deforestation Revisited. How to Move towards a Global Land-Use Transition?
}

\author{
Helmut J. Geist
}

Citation: Geist, H.J. Tobacco and Deforestation Revisited. How to Move towards a Global Land-Use Transition? Sustainability 2021, 13, 9242. https://doi.org/10.3390/ su13169242

Academic Editor: Bernard Lacaze

Received: 30 June 2021

Accepted: 13 August 2021

Published: 17 August 2021

Publisher's Note: MDPI stays neutral with regard to jurisdictional claims in published maps and institutional affiliations.

Copyright: (C) 2021 by the author. Licensee MDPI, Basel, Switzerland. This article is an open access article distributed under the terms and conditions of the Creative Commons Attribution (CC BY) license (https:/ / creativecommons.org/licenses/by/ $4.0 /)$.
Institute of Geography, University of Göttingen, Goldschmidtstr. 5, 37077 Göttingen, Germany; helmut.geist@gmx.eu

\begin{abstract}
Articles 17 and 18 of the United Nations (UN) Framework Convention on Tobacco Control address the environmental sustainability of tobacco as a contested agricultural crop. They require regulatory land-use policies to be introduced and designed to enhance a sustainability transition to diversified farming practices and/or alternative livelihoods. Related activities of the UN Study/Working Group on Economically Sustainable Alternatives to Tobacco Growing are reviewed to assess and monitor the crop's impact on natural resources with a focus on methods to identify tobacco-attributable deforestation (remote sensing, proxy values, secondary statistics, natural valuation, ecological/social surveys). It is posited that since 2007 no advances have been achieved in framing woody biomass destruction/degradation due to land extension and curing (i.e., drying green leaf using wood). Building on support by digital technologies and land surface monitoring systems, a novel post-2020 strategy is proposed to mainstream an extended set of indicators integratively, i.e., addressing biodiversity losses, soil carbon reservoirs and land degradation neutrality of tobacco as an agricultural crop. Thus, the point is emphasized that land stewardship requires political priority setting that makes the framing of land-use sustainability metrics more than a purely technical matter.
\end{abstract}

Keywords: British American Tobacco; livelihood diversification; Flue-Cured Virginia; greenwashing; land change metrics; land degradation neutrality; land health; Miombo; political ecology; sustainability

\section{Introduction}

Different from the health-related issues of individual well-being in terms of morbidity and mortality due to smoking, the negative supply-side aspects of the environmental sustainability of tobacco as an agricultural crop (N. tabacum) have received far less attention [1]. This holds true despite the fact that in 2003 the World Health Organization (WHO) unanimously adopted the international Framework Convention on Tobacco Control (FCTC), with currently 182 Parties (member states). In Article 18, the FCTC states: "In carrying out their obligations under this Convention, the Parties agree to have due regard to the protection of the environment (...) in respect of tobacco cultivation (...) within their respective territories" [2] (p. 16). It has been criticized that "before 2016, not much attention had been devoted to this Article" [1] (p. 33). Therefore, this paper sets out to trace the history of how the deforestation argument, in particular, has been dealt with in terms of consolidated land use (or land change) impact metrics. So far, a wide array of concepts, frameworks, tools and technical devices such as remote sensing (RS) or natural valuation have been applied to measure and assess tobacco-attributable biodiversity impacts. However, no useful or convincing metrics addresses deforestation in a consistent and consolidated manner, thus contributing, among others, to the failure stated above. Only in a move towards the UN Sustainable Development Goals (SDGs) since 2016, pinpointing "that health cannot be considered in isolation from a host of other factors, of which the environment is one", and that tobacco needs to be seen as "a threat to human development as a whole", a turning point in framing tobacco land-use sustainability was reached [1] (p. xii). Linking SDG concerns with integrative approaches based upon the best available global land change science and planetary (earth system) analysis, it seems possible now to mainstream a 
selected, extended set of indicators relating to biodiversity and climate change with the support of digital technologies and land surface monitoring systems [3].

\section{Controversies with Unconsolidated Land-Use Metrics}

\subsection{Origins of Tobacco Criticism and Merchandising Doubt}

Since the mid-19th century, the curing of Flue-Cured Virginia (FCV), used in cigarettes, requires wood as fuel, i.e., drying green tobacco leaves in order to achieve essential product qualities such as colour, aroma and nicotine enrichment. Until today, the majority of cigarette tobaccos are cured, either by exposing green leaf directly to smoke (fire-curing) or using a combination of external ovens and flues/pipes inside curing barns (flue-curing). A minority of tobacco varieties (for snuff, pipe and cigars) are air/sun-cured. Hardly any economically viable alternatives to wood-based energy have emerged since. In the 1880s, mechanization of cigarette manufacturing helped grow the market for cigarettes, increasing demand for FCV tobacco leaf, making $N$. tabacum the world's most widely cultivated non-food crop in about 125 producer countries [4-6].

Starting in the mid-1970s, concerns were raised about deforestation due to tobacco farming, while in the forthcoming decades transnational corporations (TNCs) in the tobacco sector have downplayed the relevance of tobacco-attributable deforestation, pointing out that they have already dealt with it through corporate social responsibility (CSR) measures. In detail, however, social construction analysis revealed industry practices-e.g., lobbying, commissioning research and colluding through agricultural "front groups such as the International Tobacco Growers' Association" (ITGA) [1] (p. 37) — that showed tobacco TNCs to divert attention from actions to respond to ecosystem impacts by emphasizing claimed substantial contributions of tobacco production (to both farmers and the state), quoting causes of deforestation as unrelated to tobacco farming and stating purportedly positive forestation results. Before the FCTC, actions to address tobacco-related deforestation had not been managed effectively [6-8].

In 2005, when the FCTC came into force, the UN Millennium Ecosystem Assessment (MEA) characterized the post-harvest, on-farm use of large amounts of wood used for curing (drying) green tobacco leaves to have a negative ecosystem impact in some countries of the global south where TNCs had shifted their worldwide production operations $(90 \%$ of present cropping on about four million hectares is located in low- and middle-income countries). The MEA criticized that the usage of wood had been considerable, and no action had been taken to potentially reduce it and thus mitigate negative side-effects [9-11].

Against this backdrop, some growing countries expressed concerns and established, under the umbrella of the FCTC, a UN Study (and later, Working) Group on Economically Sustainable Alternatives to Tobacco Growing (ESATG), effective since 2007. The group noted in 2008 that tobacco growing "may be up to 10 times more aggressive than the sum of all other factors in deforestation", and that "the global share of agricultural land used for tobacco growing is less than $1 \%$, [but] its impact on global deforestation is $2-4 \%$, making a visible footprint for climate change" [12] (p. 4). Comparing the impacts on forest ecosystems from other land uses such as palm oil, soy beans or the conversion of forests into grazing areas, the ESATG statement blends insights from secondary statistics (forest cover data) of the UN Food and Agriculture Organization (FAO) and empirical evidence provided by (independent) academic researchers. In particular, the Tanzanian ecologist Mwita Mangora was first to separate use-specific annual rates of biomass removal in the Urambo District of the Tabora Region, Tanzania's leading tobacco growing area, i.e., due to woodland clearance for land extension (creating new tobacco land) at the rate of $3.5 \% /$ year and woodland degradation due to fuelwood extraction for tobacco curing of $3.0 \%$ /year [13]. The combined figures (6.5\%), relating to FCV, were ten times above the annual deforestation rate for Africa overall (0.64\%; globally $0.22 \%$ ) [14] (Table 1$)$. 
Table 1. Deforestation attributes of Virginia tobacco farming in the Miombo ecoregion of Tanzania (flue curing/land clearing), 1959-2013 ${ }^{1}$.

\begin{tabular}{|c|c|c|c|}
\hline Study Site & Time & Method & Result \\
\hline Iringa District, Iringa Region [15] & $\begin{array}{l}\text { (1) 1959-1978 } \\
\text { (2) 1978-1999 }\end{array}$ & RS: aerial photo interpretation & Annual rates (1) $3.3 \%$ and (2) $3.0 \%$ \\
\hline Tabora Region [16] & $\begin{array}{l}\text { (1) } 1984-1995 \\
\text { (2) } 1995-2000\end{array}$ & RS: satellite imagery analysis & $\begin{array}{l}\text { (1) } 5 \% \text { and }(2) 11 \% \text { forest } \\
\text { cover removed }\end{array}$ \\
\hline Urambo District, Tabora Region [13] & 1997-2001 & FW: ecological and social survey & $\begin{array}{l}\text { Annual rate } 6.5 \% \text {, } \\
\text { or: } 61,067 \text { ha/year }\end{array}$ \\
\hline $\begin{array}{l}\text { Kipembawe Division, } \\
\text { Mbeya Region [17] }\end{array}$ & February-September 2013 & FW: ecological and social survey & $\begin{array}{l}\text { Annual rate } 0.6 \% \text {, } \\
\text { or: } 4134 \text { ha/year }\end{array}$ \\
\hline
\end{tabular}

${ }^{1} \mathrm{FW}=$ Fieldwork, RS = Remote sensing.

In sum, concerns about tobacco-related deforestation—-dating back to the 1970s and including high-level warnings from the MEA - triggered the enhancement of the FCTC Article 18 in 2003 and the ESATG process starting in 2007. Most importantly, the 2008 ESATG statement about tobacco triggering "aggressive" deforestation [12] (p. 4) has not been disputed or refuted since but carried on in subsequent reports. Thus, it holds validity, especially with regard to the geographical area from which evidence had been generated. For example, in comparison with other sources-be these industry-mandated work [18-20] or independent academic research [21-23] — results confirm the overall notion that the Miombo ecoregion in southeast-central Africa not only holds $90 \%$ of all land under tobacco crops on the African continent, but also constitutes a global hotspot of tobacco-attributable deforestation. Results from mostly RS-based studies suggest that in the African ecoregion the annual, tobacco-attributable biomass loss accounts for up to half the losses of woodland and forest there [23-25] (cf. Table 1).

\subsection{Most Recent Industry Reaction and Still No Metrics Available}

Reacting to ESATG activities, the ITGA commissioned business consultancy work in order to assess and estimate the effects of the tobacco industry on deforestation [20]. As in the work of Mangora [13], a difference was established between deforestation for land extension and deforestation due to wood-based curing, with different calculations associated with each land use impact. First, FAO secondary statistics was used to assess changes in forest cover and agricultural area in relation to crop-specific ratios (area harvested/total agricultural area); comparing the time periods 1990-2000 and 2000-2007, statements were generated about countries with negative forest area change such as that the tobacco crop shifted from a "secondary" to a "main driver" of deforestation in Brazil (aside from soybeans and wheat) and in Malawi (single main driver in 2000-2007); overall, it was concluded that tobacco's share in global deforestation "due to agricultural expansion is smaller than for other crops" [20] (p. 28), confirming the (unsubstantiated) ITGA claim that tobacco has a lower environmental footprint than many other crops [19]. Second, FAO data in combination with crop-specific wood consumption data and mean increment values of area-specific biomass growth were used to assess curing-attributable deforestation, i.e., tobacco production using wood, the wood requirement for tobacco varieties, estimation values of wood required and (assumedly) taken from open/common land and sustained-yield area of woody biomass needed to provide wood for curing. Thus, tobacco-attributable deforestation "can be estimated (...) for different assumptions of wood requirement for the curing process $(3,5.5,8.6$ and $30 \mathrm{~kg}$ wood $/ \mathrm{kg}$ tobacco) for the year 2009. Values are calculated for a share of wood-based flue-curing of $19 \%$, a grade of self-sufficiency of $42 \%$ (global mean value), and a mean annual increment of $15 \mathrm{~m}^{3} /$ ha and a growing stock of $27 \mathrm{t} / \mathrm{ha}$. Based on these values, the share of the curing process on deforestation is between $0.7 \%$ and $7.5 \%$, whereas the extreme values on both sides may be not realistic scenarios on the global scale. It can be assumed that the estimated tobacco's share on deforestation due to the curing process is between 1 and 2\%" [20] (p. 24f). By 
specifying such range, the business consultancy study encloses the mean value of 2 to $4 \%$ used in the ESATG process [12] (p. 4) rather than discrediting it (still, both figures relate to curing-attributable deforestation only). In contrast to most RS-derived input into the ESATG process (cf. Table 1), however, the consultancy study falsely claims that "there is no data available, which would show the impact of the tobacco production and other crops on deforestation directly" [20] (p. 16).

Notwithstanding the importance of some insights generated about tobacco-attributable deforestation since the start of work by ESATG, the point is made that blending qualitatively different data sources in combination with applying various techniques or methodologies has not helped to contribute to an accurate and agreed upon picture concerning tobacco land use and ecosystem impacts. An array of models, concepts, tools, indicators and devices have all been applied aside with each other in an unrelated and theoretically untidy manner, be these aerial photo interpretation, satellite-based remote sensing (Landsat data, mainly), evaluation of secondary statistics (FAO data, mainly), extrapolations from proxy values (biomass growth, crop-specific wood consumption), ecological transect analysis, physical stackwood measurements and/or farming and household surveys. The result is that one decade after FCTC implementation, issues of tobacco land use sustainability are still dealt with in a controversial manner and with no consolidated land change metrics available.

\subsection{Realizing Ecosystem Impact and Greenwashing}

In the aftermath of 2010, the controversy about tobacco was seemingly driven towards a turning point of how to frame the crop's environmental sustainability. The then underlying motivation was to reduce serious operational and reputational risks inherent to business sectors with extensive global supply chains and comparable sensitive, ethical situations such as retail, food, nuclear, weapons and information/communication technology [26]. Some TNCs such as Philip Morris International (PMI) and British American Tobacco (BAT), therefore, started to embrace CSR activities such as environmental stewardship in terms of natural (or ecosystem) valuation, biodiversity partnerships (stakeholder marketing) and "good agricultural practices" (GAP) as promoted by the Cooperation Centre for Scientific Research Relative to Tobacco (CORESTA) $[27,28]$. The move towards environmentalism had been due-not to pressure built up by ESATG, but-to the global finance (investment) sector and some national governments (notably, the environment ministers of G8 countries). Following up on the MEA approach to link supporting, regulating, provisioning and cultural ecosystem services with human well-being, the group of governments triggered an initiative to promote the economic valuation of natural resources. The action was inspired by the Stern review on the economics of climate change, recognizing substantial market failure and suggesting early action to outweigh future costs [29]. Following suit, a study on the economic significance of the global loss of biological diversity, termed The Economics of Ecosystems and Biodiversity (TEEB), was launched in 2007. Its aim was to compare the costs of a decline in biodiversity and ecosystem services with the costs of effective conservation and sustainable land use. As part of the second TEEB phase, starting in 2009 (i.e., call for evidence, targeting end-users), the UN Environment Programme (UNEP) together with the World Conservation Union (IUCN) began to co-ordinate work on the agro-food business sector, among others. Not surprisingly, the tobacco sector was included in analyses to provide evidence of growing corporate concern about biodiversity loss, thus responding to demands established by the global finance industry responding to changing consumer preferences [26].

Driven by the TEEB effort, tobacco TNCs that run own or contracted overseas farming operations became central for further investigation. Summarizing recent evaluations of attempts to assess the level of biodiversity risk, TEEB concluded that in the tobacco sector (a) risk levels are medium, (b) "social issues overshadow environmental [impacts]", and (c) "moderate dependency exists on (...) timber for curing" [30] (p. 62). In terms of measuring and reporting, "weaknesses in biodiversity targets" have been identified for several 
tobacco enterprises (and, typically, in the extractive industry as well): "The information presented (...) is rarely sufficient to enable external stakeholders to form an accurate picture of companies' efforts to assess, avoid, mitigate or offset their impacts" [31] (p. 89). It was acknowledged though that in some cases, focusing on impacts and dependencies related to harvesting and production of raw materials, the Ecosystem Services Benchmark device has been applied; the latter is a tool kit-not to quantify tobacco-attributable deforestation, but - to be put into practice as "a useful framework for planning and monitoring" in order to support the (financial) asset management community as well as the banking and insurance sector to evaluate environmental risks and opportunities of investments. However, and with reference to the absence of a consolidated land use change metrics, it was noted that companies in the tobacco sector "produced limited public disclosures, rarely stated clear targets and used mainly qualitative data (e.g., case studies, descriptions of initiatives) to communicate their management of biodiversity and ecosystems, rather than quantitative indicators of performance" [31] (p. 114).

Overall, evidence has been confirmed through TEEB that tobacco TNCs such as BAT, PMI and other companies give the appearance only of complying with environmental standards in their implementation of natural valuation tools and green CSR campaigns, thus giving tobacco farming the image of an environmentally friendly activity, while continuing with business as usual. Likewise, global leaf trading companies such as Alliance One International, Dimon and Universal Corporation have been shown continuing to purchase leaf produced from tobacco farmers in hot spot areas of land cover change (cf. Table 1), thus contributing to deforestation through tobacco cropping and curing [1,7]. After decades of mainly ITGA-orchestrated merchandising of doubt, the tobacco business sector finally acknowledged in a BAT-commissioned consultancy study, in the same year when TEEB results were published [26], that "[deforestation] may be the single most negative impact of tobacco cultivation on the environment (...) given the results of the study by Geist et al. (2009)" [8] (p. 55) (according to [32]). The work mentioned is a panel study integrating local farming surveys in Africa, Asia, America and Europe (using a common data protocol) with an assessment of secondary data and statements generated on the occasion of a FCTC public hearing on crop substitutes and livelihood diversification [33]. This implies that namely BAT recognized the validity of (independent) tobacco-related deforestation research and the herewith associated need for a change towards sustainable tobacco land-use policies.

\section{Post-2020 Mainstreaming of Extended Indicators}

\subsection{Redirecting towards SDGs and Rio Commitments}

Having established no relations to MEA and TEEB, the ESATG process was based upon the notion that framing the (disputed) environmental sustainability of tobacco as a crop could be achieved in a rational, positivist manner as it has been done with the disease impact of smoking in terms of public health/public policy. There was (and still is) a strong belief that a three-step policy design, based upon empirical research evidence, could be implemented for deforestation in manner that is unrelated to other land changes: (a) perform a baseline assessment (situation analysis): "Has your country executed studies on the extent to which deforestation or forest degradation is due to tobacco cultivation?"; (b) "process to be undertaken to change the situation": "Collect data and quantify deforestation and forest degradation due to tobacco cultivation (change of land use and for curing purposes)"; (c) "expected outcomes": "Impact analysis of deforestation and forest degradation based on tobacco cultivation requirements" [34] (pp. 17-23). Principles and guidelines were laid out that were thought to be relevant for land-use metrics: e.g., generate "credible evidence" from subnational "independent studies", fit them into methodologically standardized "environmental impact assessments" and carry out monitoring and evaluation on a regular basis (Table 2). It can be safely stated that the ESATG approach failed because it (re)iterated already published information that had been created by independent researchers or mandated by tobacco control advocacy groups, as is obvious from the most recent compilations of the tobacco-environment nexus [1,35]. Furthermore, and most importantly, in its search 
for "impact indicators for Article 18", ESATG reduced the real-world complexity of land use and posited a single quantification measure of land cover change: "Percentage of the loss due to forest degradation and deforestation in tobacco growing areas and in alternative crop areas" [34] (p. 23). The latter was merged into one package together with indicators about the prevalence of child labour and green tobacco sickness, an occupational disease among farm workers.

Table 2. ESATG principles and guidelines with relevance for land change metrics.

\begin{tabular}{|c|c|}
\hline $\begin{array}{c}2008 \\
{[12](p .9)}\end{array}$ & $\begin{array}{l}\text { "Standardized, regularly collected data are needed on }(\ldots) \text { environmental issues, and independent studies } \\
\text { should be conducted, especially in less developed countries, that provide credible evidence." }\end{array}$ \\
\hline $\begin{array}{c}2012 \\
\text { [36] (pp. 14-22) }\end{array}$ & $\begin{array}{l}\text { "In promoting research .... to identify and develop effective strategies for alternative crops and livelihoods } \\
(\ldots / \ldots) \text {, each country should undertake environmental impact assessments of tobacco activities to determine } \\
\text { the levels of deforestation, forest degradation, }(\ldots) \text { climate change effects }(\ldots) \text { and other ecological effects."In } \\
\text { an effort, to "develop environmental regulations that protect and conserve the environment from tobacco } \\
\text { farming activities }(\ldots / \ldots) \text {, zones in which tobacco is grown should ... be mapped, restricted in terms of size } \\
\text { and approved by relevant government authorities to protect fragile ecosystems from destruction". }\end{array}$ \\
\hline $\begin{array}{c}2014 \\
\text { [34] (pp. 11-17) }\end{array}$ & $\begin{array}{l}\text { "Expected results" should be based on "updated studies prepared of the environmental (...) impacts of } \\
\text { tobacco growing by region in each country." "Parties should undertake initiatives to monitor } \\
\text { deforestation"."Monitoring and evaluation are key elements }(\ldots) \text { for implementation of }(\ldots / \ldots) \text { Article } 18 \text { to } \\
\text { mitigate the }(\ldots) \text { environmental harms related to tobacco production".."Each country should compare the } \\
\text { impacts of tobacco growing to those of alternative crops, in respect of the level of deforestation }(\ldots) \text { and other } \\
\text { ecological effects", with all information required to follow "standardization of methodology and } \\
\text { approaches"."Parties should undertake measures to prevent and to recover areas already damaged by } \\
\text { tobacco production". }\end{array}$ \\
\hline
\end{tabular}

Due to the combined effects of TEEB pressure, novel planetary (global land change) science thinking and the normative imperative of UN's framing of sustainable development strategies, it is now possible to abandon the isolated treatment of tobacco-attributable deforestation in the ESATG-approach and put into practice a much broader framework encompassing stewardship of terrestrial ecosystems. The turning point in framing tobacco land-use sustainability rests on sustainability thinking stating, "that health cannot be considered in isolation from a host of other factors, of which the environment is one", and that tobacco needs to be seen as "a threat to human development as a whole" [1] (p. 12). Subsequently, at the Conference of the Parties (COP) to the FCTC in 2018 it was decided, with regard to the implementation of Article 18, "to invite Parties to engage in collaboration across sectors at mitigating the environmental damage caused by tobacco $(\ldots)$, to raise awareness $(\ldots)$ on the impact of tobacco cultivation $(\ldots)$ on ... the terrestrial ... environment and (...) share best practices to address the environmental externalities associated with tobacco growing" [37] (pp. 2-3). This meant a crucial momentum for opening up "supply-side effects of tobacco control policies" that were originally framed with no relation to ecological (or planetary) issues such as biodiversity losses, sustainable agriculture and land health [38]. The road ahead is now as follows: "It is clear by now that tobacco control intersects with other pressing global issues such as those addressed by the SDGs, the Rio+20 environmental commitments, climate change science, new global trade agreements, and environmental justice" [1] (p. 37).

Tobacco control policy, in general, is linked to 66 of the SDG targets, in addition to the direct disease impact of smoking on human health (SDG 3, healthy lives and well-being for all) [35]. Most importantly, Land Degradation Neutrality (LDN) became the leading goal of international policy about sustainable land stewardship, forming an integral part of the UN Convention to Combat Desertification (UNCCD). By definition, LDN "is a state whereby the amount and quality of land resources necessary to support ecosystem functions and services and enhance food security remain stable or increase within specified temporal and spatial scales and ecosystems" [39] (p. 8). With the inclusion of LDN in the list of SDGs, the target of achieving a "land degradation-neutral world" by 2030 was agreed upon in 2015 (SDG 15 and 15.3). In relation to tobacco-attributable deforestation, this implies 
offsetting land degradation caused by forest removal for land extension in situ and/or forest degradation for wood-based curing at other sites with the result that continuing degradation is halted and LDN achieved. Matching the time frame of implementing SDG 15.3, the UNCCD's 2018-2030 Strategic Framework specified broad goals in order to achieve meaningful multiple benefits, i.e., restoring, protecting and sustainably using ecosystems as indispensable prerequisites for the protection of biodiversity, mitigation of climate change and design of a sustainable agro-food system [3].

In terms of international co-operation and co-ordination, it is noteworthy that the protection and use of land are not primarily negotiated in a single intergovernmental forum. Rather, land-use changes are dealt with by various international institutions, organizations and forums (or summits). For example, land-derived ecosystem services are dealt with and regulated by the three so-called Rio Conventions, i.e., UNCCD, Framework Convention on Climate Change (UNFCCC) and Convention on Biological Diversity (CBD). In this regard, the goal of LND gained international consensus only at the World Summit on Environment and Development in Johannesburg 2012 (Rio+20). Albeit setting own priorities, every convention prioritizes land stewardship, i.e., prevention and neutrality of land degradation (UNCCD), climate change impacting on cultivated land and land conceived as sink and source of greenhouse gas (GHG) emissions (UNFCCC), and sustainable use and conservation of terrestrial ecosystems and their biodiversity (CBD). For land-based tobacco control, it is crucial to see that a systemic and encompassing land management approach will generate potentially high synergies through mutual mainstreaming of land-based concerns across sectors [3]. However, the potential will only be realized, if a co-operative stance is used to exploit multiple benefits (as taken already by CBD and UNFCCC). If supply-side elements of the FCTC are to make use of this potential institutionally, they would need to be linked to activities by a Joint Liaison Group (JLG) of the executive offices of the UNCCD, CBD and UNFCCC. JLG was established in 2001 with a focus on co-operation on land-related issues, among others. As for supply-side tobacco control, the move to link to JLG has already been demanded from 2017 onwards, i.e., enhancing possible synergies in procedures, data pools and monitoring and/or reporting requirements and feeding them, if political will exists, into the ESATG-process $[1,37]$.

Multilateral co-operations such as FAO, UNEP and the Global Land Programme (GLP) can be important actors, and many more agreements further influence the way how land is used and managed. Overarching goals are LDN and other SDGs such as SDG 15 (life on land) aiming to "protect, restore and promote sustainable use of terrestrial ecosystems, sustainably manage forests, combat desertification, and halt and reverse land degradation and halt biodiversity loss" [40] (p. 24). Albeit UN SDGs are invaluably important concerning their political integration and umbrella functions, it has to be noted that there are no legally binding instruments to mitigate contradictions or overlaps concerning e.g., nature protection and world trade [3]. Therefore, especially for ecologically sensitive tobacco growing areas in ecoregions such as Miombo (cf. Table 1), the SDGs offer an opportunity to organize a sustainability transition away from an environmentally damaging crop. This might attract some growing countries in the global south (e.g., Tanzania and Malawi, both situated in the Miombo ecoregion) that depend on tobacco and refrain from becoming Parties to the FCTC, thus not exploiting the chance of joining the ESATG-organized process of a sustainability transition [41].

\subsection{Striving for Sustainable Land Stewardship}

The redirection of ESATG activities away from a single item-focused, linear approach for Article 18 (deforestation baseline > process > outcomes) to a much broader perspective of transforming towards sustainable land stewardship is due to the incorporation of systems-oriented global land change science [42,43]. This strand of planetary, climate change-oriented research acknowledges the fact that the transformation of terrestrial ecosystems is largely driven by the way how global business supply chains are organized [44]. The scientific rationale for action rests on the assumption that a "trilemma of land use" ex- 
ists as pinpointed by the German Advisory Council on Global Change (WBGU) [3] (p. 22). The trilemma is about the interference of three global crises, namely climate, agro-food and biodiversity: "The current destruction, degradation and fragmentation of terrestrial ecosystems is accelerating anthropogenic climate change, driving biodiversity loss and impairing food security. All three crises, each in its own way, are related to the use of land or terrestrial biomass and, in turn, have an impact on global land use and terrestrial ecosystems" [3] (p. 22). The WBGU's basic view is that "our current global approach to land stewardship is an acute, systemic problem, but one that we can solve by taking smart, synergistic action and assuming solidarity-based responsibility in multi-actor partnerships" [3] (p. 229). For this to achieve, a set of three coherent indicators has been suggested in relation to complementary and closely interlinked policy goals, i.e., climate change mitigation, biodiversity conservation and agro-food sovereignty. Most importantly, indicators were selected on the basis that they (a) depict most acute crisis conditions, (b) have synergies for sustainable land development and (c) can be supported simultaneously by multiple-benefit strategies [3] (p. 225). The potential interplay of multiple-benefit strategies in the tobacco sector is outlined below.

\subsubsection{Climate Change, Forestry and Curing Technology}

From 2007 to 2016, land use changes caused 23\% of GHG emissions, thus contributing to continued climate change (the 2015 Paris agreement limits Earth temperature increases to between $1.5^{\circ} \mathrm{C}$ and $2{ }^{\circ} \mathrm{C}$, currently $1.1^{\circ} \mathrm{C}$ ) [45]. Regarding adaptation and mitigation to climate change, a transformation of current land management practices deems unavoidable for a variety of interlinked reasons. First, present land use/cover changes-the conversion of natural cover into agricultural land, mainly-not only cause emissions (to be reduced), but also remove carbon dioxide $\left(\mathrm{CO}_{2}\right)$ from the atmosphere (forming a sink for $\left.\mathrm{CO}_{2}\right)$. Second, the projected massive impacts of climate change (even if abated) will require substantial adaptation of land use (shifts of agriculture's physical geography) so that sustainable land stewardship strengthens the resilience to climate impacts overall [3]. Land uses account for $\mathrm{CO}_{2}$ emissions as well as nitrous oxide $\left(\mathrm{N}_{2} \mathrm{O}\right)$ and methane $\left(\mathrm{CH}_{4}\right)$ emissions, but the latter have a limited lifetime in the atmosphere (no need to be reduced completely). However, $\mathrm{CO}_{2}$ does not chemically decompose in the atmosphere and thus needs to be brought back to zero (to stop climate change). A major process to remove it from the atmosphere is photosynthesis (plants and sunlight breaking down $\mathrm{CO}_{2}$ and producing biomass through $\mathrm{CO}_{2}$ transformation) [3,45]. The hitherto undisputed baseline concerning tobacco as an agricultural cop is the ESATG statement that "its impact (...) mak[es] a visible footprint for climate change" [12] (p. 4). In this context, multiple benefits from sustainable land use arise when ecological restoration is done in tobacco growing areas, i.e., measures to promote rehabilitation and/or recovery of land damaged by tobacco cropping [46]. This means that land previously under tobacco is not destined to be returned to a pristine state but put on the trajectory of sensibly designed land management in order to adapt to and/or mitigate climate-change [3].

- Forest-related ecological restoration: Unless implemented in monoculture such as timber plantations, forestry helps to restore relevant ecosystem services and promises substantial global sequestration potential of $\mathrm{CO}_{2}$. Depending on the assumed time horizons, this involves reforestation of deforested land as well as afforestation of non-forested areas. During tree growth, atmospheric $\mathrm{CO}_{2}$ is fixed and stored in the biomass of shrubs, woodland and trees or in wood products [3]. In a set of guiding principles, IUCN stresses that the crucial point in afforestation is the influence it exerts on biodiversity and soil carbon [47]. Negative side-effects and risks usually emerge due to exotic species, especially the spread of non-indigenous, fast-growing trees $[3,47]$. In this regard, eucalyptus has been preferred in many, if not most planting schemes organized by tobacco companies $[7,48,49]$. They can change the balance of soil water and nutrient flows, particularly in (semi)arid areas such as the Miombo ecoregion [3]. However, published evidence of forestation activities is scarce as stated 
even in industry-mandated work: "Unfortunately, it is difficult to find reports on treeplanting and other activities by the tobacco industry" [20] (p. 29). Notwithstanding negative side-effects, forest-related restoration remains a key ecosystem impact that matches the LND goal of offsetting tobacco-attributable land degradation caused by forest/woodland removal (clear cutting) or forest/woodland degradation (curing). It is also part of a multiple-benefit strategy to overcome the land use trilemma, since forests/woodlands play an important role in providing non-timber forest products to the rural population (e.g., bushmeat, fruits, mushrooms, herbs, berries), thus having the potential of forming essential pillars for the livelihoods of farming communities, in general, and tobacco farming households wanting to transform into more diversified land management, in particular [3].

- Changes in curing technology: Albeit land stewardship such as ecological restoration is substantial to overcome the climate crisis, taken alone it is insufficient [3]. If global climate mitigation/adaptation as laid down in the Paris agreement is to be made successful, there is wide agreement that $\mathrm{CO}_{2}$ emissions from fossil fuels such as coal, oil and gas need to be reduced rapidly [45]. Therefore, as an immediate action traditional curing barns that use wood (loosing up to $99 \%$ of energy such as in Zimbabwe) are required to shift to more wood-efficient barn curing technology such as rocket barns (though, still losing 56\% of the energy supplied) [50]. Alternatively, biomass "waste material" such as rice husks "is fully sustainable and cost-effective if (...) readily available" [20] (p. 35). Other biomass-based usages include charcoal, organic waste products (coffee husks, olive stones, coconut shells, sugar cane bagasse, groundnut hulls) and briquette fuel produced from these or other organic material [51,52]. In a second step and given the fact that most wood for curing is taken from forested customary land and to a lesser degree from forest reserves (and other sources) $[4,9,10,18,20,48,53]$, the goal of a tobacco farm's self-sufficiency in sustainably sourced wood is paramount. CORESTA's benchmark indicators are as follows, albeit unspecified and opaque: "\% of renewable fuel consumed for tobacco curing, $\%$ of alternative fuel (biomass) consumed for tobacco curing, $\%$ of wood fuel from a sustainably managed source and consumed for tobacco curing" [28] (p. 40). Fossil fuel-based curing technologies such as electricity from coal/oil/gas-powered plants or the direct usage of coal as recommended, for example, in Zimbabwe in order to replace wood [54], do not contribute to a multiple benefit strategy. Thus, scope for improvement in curing barn energy efficiency is limited regarding potential to improve barn construction materials, on-farm storage and curing process management. Likewise, as a primary or supplementary heat source "alternative thermal and electrical energy sources such as solar and wind power are used on a limited basis" [28] (p. 39).

In sum, both ecological restoration of tobacco land and technological adjustments in tobacco curing offer opportunities to overcome the overtly rigid focus of ESATG's activities on tobacco's environmental impact using single metrics only, i.e., percentage of deforestation caused by the crop (in comparison with other crops). In contrast, the WBGU approach not only addresses widespread agricultural crisis conditions, but more so has synergies for sustainable land development and supports multiple-benefit strategies. It helps to overcome deficiencies of concepts such as the calculation of carbon footprint measures that are mostly used in WHO-commissioned studies [1,35]. However and typically, at some stage of developing an argument for action, footprint approaches will suffer from data deficiencies: "Due to a lack of robust data on the deforestation caused by tobacco farming and the unsustainably sourced wood for tobacco curing, the impacts of smoking on climate change and ecosystems' health could not be fully captured" [35] (p. 20). On the other hand, industry-mandated work has since long sent warnings "that the consequences of deforestation, especially in the arid and semi-arid areas, are so serious that all wood users must take steps to conserve the existing resource and create new plantation supplies for the future" [18] (p. 32). Thus, abandoning the framing of tobacco's environmental sustainability in footprint and related metrics (e.g., natural valuation), forestation and 
curing approaches show a way forward as a move towards sustainably sourced wood providing tobacco farmers with an incentive to adjust to sustainable land stewardship in a foreseeably challenging period of a transition to other land uses (see Section 3.2.3). Most importantly, the ecological restoration approach is "already available and tested today, (...) a comparatively low-risk and relatively low-cost strategy, especially in the context of the land-use trilemma" [3] (p. 64). Taken together, mature techniques of re/afforestation can already be implemented or help replace mono-cultural timber plantations in many tobacco growing areas without high technological requirements. The issue of changing curing technology is more challenging in that it implies, at first instance, a shift away from artificially cured tobacco varieties using coal, oil and gas to naturally cured varieties (using air and sun). In a second move, it would require a change in consumer preferences, i.e., away from FCV for the manufacture and mass consumption of (white, stick, filtered) American blend-type cigarettes to, for example, bright sun-cured Oriental (or Turkish) tobaccos for blends of pipe, to shade-cured tobacco used in hand-rolled or chewing tobacco and/or to dark air-cured cigar tobacco varieties $[5,55]$.

\subsubsection{Biodiversity Conservation, Field and Soil Management}

In 2005, with special regard to tobacco cropping, the MEA [9-11] and subsequent studies $[26,43,56]$ have shown that biodiversity overall, i.e., the biological diversity of genes, species and ecosystems, is immensely important for the well-being of humans, namely regulatory, material and non-material ecosystem services provided to humans that for themselves constitute a habitat for plant and animal species (with plants accounting for $83 \%$ of global biomass), thus generating essential foundations for human existence. For example, over $50 \%$ of the naturally regulatory ecosystem services (e.g., storage of $\mathrm{CO}_{2}$ by trees, water purification by forests) has a direct impact to overcoming the agro-food and climate crises. However, their growing endangerment implies that all biodiversity-related services are in danger as well $[43,57]$. As a matter of fact, all biomes and terrestrial (or land) ecoregions (14 biomes and 846 ecoregions in total) are affected by biodiversity loss. Among the direct causes are agricultural land-use changes triggering the large-scale destruction of natural ecosystems, habitat fragmentation and species decline (if not extinctions). Overwhelmingly, the indirect (or underlying) drivers point to globalization, namely international trade and its effects. The direct (or proximate) drivers induce losses of biodiversity due to the monotonization of landscapes (rather than favouring agro-diversity), and indirect (or telecoupling) effects reveal associated production and consumption patterns due to people's lifestyles in remote parts of the world, including smoking [44,58]. Thus, the complex conflicts of interest between human actors in relation to land-based ecosystem services need to be addressed in an equally complex framework. The crucial point is that the global loss of biodiversity and the threatening complete loss of individual services are irreversible, but the worldwide degradation of ecosystems can be halted and, at least in parts, be reversed through ecological restoration (see Section 3.2.1) and soil conservation [3].

- Sustainable land management (SLM): Relating to climate change in Sub-Saharan Africa, in particular, it has been criticized that "SLM ... by farms does not appear to be seen as an adaptation priority. (...) However, sustainable land and soil management is essential to the question of whether there can be a future for agriculture in the semi-arid regions of Africa" [3] (p. 123). In this context, SLM measures will need to address (a) biodiversity losses through land conversion from near-natural land cover to agricultural uses (halt land clearance for tobacco), (b) agro-diversity losses by vegetation disturbances on farming plots that receive, for example, massive dosages of insecticides (replace tobacco by crops demanding less artificial agents), and (c) genetic variety of crop species (phase out FCV monocropping) [59]. CORESTA's GAP framework sets out general key pillars of good tobacco farming practices [27], and specific guidelines for sustainability in leaf production have been specified as follows: (a) technologies to improve the efficiency of water use on seedlings by means of hydroponics and micro-irrigation, for example, but also to improve input/output 
relations and soil management; (b) rotating crops as part of field crop management as beneficial techniques to preserve nutrients and manage pest and diseases, among others; (c) soil conservation measures in the form of widely spaced tobacco plants (e.g., contour ploughing) in order to avoid soil erosion, in particular; (d) nutrient management to strictly follow recommended fertilizer application measures (avoid excessive dosages, etc.); (e) in field water management, exploitation of multiple synergies regarding soil conservation such as rainwater harvesting and storage through contour bunding, among others; (f) integrated pest management to adopt, for example, biological, mechanical and physical strategies for the reduction in crop losses caused by disease/pest attacks, thus limiting the usage of artificial crop protection agents. These principles (or guidelines) are supported by vaguely specified indicators such as percentages of farmers that practice them [28].

- Soil carbon sequestration: Agro-forestry as well as forestry practices (see Section 3.2.1), even when slight adjustments are made towards improved tree management, will increase carbon sequestration in both forest and agricultural soils when trees are integrated. Such as in SLM, this is achieved through adjustments in harvesting and nutrient management, enriching soil carbon content and extracting $\mathrm{CO}_{2}$ from the atmosphere. More so, soil and land health are stabilized (quality, richness of nutrients) and the risk of soil erosion minimized [45]. In this context, and not only considering the use of wood for tobacco curing, agro-forestry measures are important since they ameliorate properties of the soil through the integration of commercial trees (wood, fruit) such as shrubs, palms and bamboo, and since they diversify cultivation and nutrition, thus reducing and/or avoiding livelihood risks (see Section 3.2.3). Worldwide, these farming practices have a long tradition and are considered since the 1970s to play a crucial role in (sustainable) agricultural development [3]. Additionally, they provide abundant synergies and multiple benefits (e.g., shade production, nutrient recycling, water storage, generation of humus) [3]. However, agro-forestry is largely absent from the way how CORESTA conceives sustainable tobacco leaf production, i.e., focusing on individual (simplified, monotonous, standardized) tobacco cropping rather than embarking on diversified and multifunctional farming practices.

In sum, both SLM measures and soil carbon sequestration help widen the rigid focus of ESATG's activities on tobacco's environmental impact using deforestation metrics only. Against the background of the global biodiversity crises, a new, sustainable approach to tobacco land stewardship is needed in the form of an integrated strategy. Given that externalities and costs of tobacco production, for example, have as yet not been adequately internalized along agricultural supply chains, the FCTC/ESATG-process remains charged with urging policy-makers to establish meaningful conditions for a tobacco landuse transition and, even more so, create incentives for society (consumers/smokers) to change preferences as well as obligations for business (tobacco TNCs) to apply useful technologies to achieve greater sustainability within the economic and political FCTC control system $[1,3,44,56]$. With considerable deforestation due to agricultural practices, the Miombo ecoregion is illustrative of this (cf. Table 1). For example, crops such as maize and tobacco replaced $74 \%$ (or 2.8 million ha) of forest cover, in the east of Tanzania alone between 1908 and 2000, thus triggering substantial deforestation-attributable GHG emissions [25]. In the Miombo zone (as in other ecoregions), measures of SLM and soil carbon sequestration can potentially reduce land degradation impacts in situ as they improve the efficiency of land resource use through ameliorating cropping patterns. In combination with improved tobacco curing technology, they may help to avoid renewed land clearances for tobacco, be these practices of swidden cultivation by smallholders and/or large-scale clear cutting by plantation owners/managers (see Section 3.2.1).

\subsubsection{Biomass Prioritizing, Crop Substitution and Livelihood Diversification}

At present, the usage by humans of food, wood, feeds and fibre consumes around $25 \%$ of the globe's potential terrestrial net primary production. Since the amount of biomass 
generated by ecosystems is limited by the extent and quality of the global land surface, an unlimited expansion is not possible $[45,56,60]$. On the other hand, the proportion of chronically hungry people in the world population has been stagnating since 2015, while absolute numbers are on an increase since then (currently 690 million humans). Aside with hunger, malnutrition is another issue, i.e., the absence or scarcity of trace elements, vitamins and/or minerals. Overall, about two billion people suffer from severe or moderate food insecurity [61]. In this context, current agro-food production systems have multiple negative, local-to-global impacts on environment and climate, mainly due to their high intensity of resource use such as the agro-industrialized mode of FCV cropping [45,61].

In general, an integrating and strategic view is required that is suited to connect landuse policy synergies with the dimensions of the land-use trilemma. Therefore, competing land uses and/or land claims need to be balanced and prioritized. Above all, and in order not to violate fundamental human development rights such as SDG 2 (ending hunger by 2030), it has been suggested by the WBGU to apply the principle of "a hierarchy in the use of biomass" [3] (p. 6). It means the low ranking of agricultural land for nonfood crops (such as N. tabacum) and of specific wood-based energy uses (such as tobacco curing) in favour of food security and food sovereignty. In this regard, reference can be made to a crucial statement generated by the MEA: "[Non-tobacco growers] manage more diverse and stable agro-ecosystems, produce more food, and show a stronger negotiating capacity within the political process. The strategy of tobacco growers, in contrast, depends far more on the agroindustry. They produce less food, have very limited negotiation power, and are more exposed to the control of tobacco companies and the fluctuations of tobacco prices and industry" [11] (p. 159). Thus, even before ESATG had started supplyside regulation thinking, the MEA already captured what the WBGU later describes as "a systemic connection between the problems of over- and malnutrition and the environmental problems connected with industrialized agriculture" [3] (p. 26). It reflects a situation where the industrialized, globalized agro-food system (with the tobacco business being evidence of this) is controlled by a rather small group of leading actors such as BAT, PMI or the Chinese National Tobacco Corporation (CNTC), benefitting from economies of scale through the management of global agricultural supply chains and promoting (in the case of seeds and varieties such as FCV) the monotonization of landscapes and large-scale biodiversity losses [44,62].

In this regard, the ESATG group has, in addition to FCTC Article 18, another mandate which is to implement Article 17 (development of an alternative farming model) by outlining policy options and recommendations how a shift to sustainable alternatives to the production of $N$. tabacum could be achieved. A sustainable livelihood approach has been proposed: "Many countries, including the world's largest producers are taking steps to find alternatives to tobacco growing. Several economically sustainable alternatives ... have been identified in studies in various regions of the world. (...) Not only income and crop profitability but all aspects of farmers' livelihoods need to be addressed. A framework for alternative livelihoods that addresses the problem holistically could form a bridge between academic findings and policy decisions" [34] (p. 4). The baseline is that "the principle of livelihood diversification goes beyond the idea of substituting one crop with another", and that "alternatives should be developed under the principles of promoting sustainable development (...), enhancing the ability of growers to manage natural resources sustainably with lower negative environmental impacts, increasing resource efficiency and reducing waste" [34] (p. 7). In essence, the effort is about a large-scale sustainable development project, i.e., "to allow a transition to agro-ecology, recover soil fertility and preserve biodiversity" [34] (p. 10). In order to frame and promote research, it is recommended to follow a "standardization of methodology and approach", borrowing from rural development science with a particular focus upon food/livelihood security; therefore, "data of land-use patterns should be collected in tobacco-growing areas, to find out if land used for food crops has been transformed into tobacco-growing land or vice versa" [34] (p. 11). The set of indicators chosen to monitor and evaluate progress together 
with its underlying principles mimic that of deforestation metrics (and principles), i.e., constituting a rational-positivist approach of an evidence-based policy design that follows a linear, three-step implementation: situation analysis > process (to change situation) $>$ (expected) outcomes (see Section 3.1, cf. Table 2). Likewise, indicators for Article 17 are similar, if not identical, to those for Article 18 in that the real-world complexity of land change is reduced to a single metric, i.e., the "number of percentage of tobacco growers fully/partially shifted to alternative crops and other livelihoods" [34] (p. 21).

While the tobacco industry through its agricultural pressure groups (mainly ITGA, to a lesser degree CORESTA) continues to claim that no economically sustainable alternatives to tobacco land use exist, especially for smallholders in the developing world [33], a compilation of three national case studies by the International Development Research Centre (IDRC) presents findings and insights to the contrary.

- The Government of Bangladesh, for example, is a Party to the FCTC. After environmental regulation and enforcement failed to halt tobacco-attributable deforestation, it indicated to assist FCV farmers in identifying alternative land uses from 2009 onwards and, finally, in 2013 removed all state incentives to tobacco production in food-producing areas (with banks following suit regarding loans, etc.) [63]. From the viewpoint of food security, FCV monocropping disrupts other crop cycles when it comes to land-use decision making on planting, harvesting, etc. FCV actually denies the potential for triple cropping which makes land use essentially inefficient, thus creating bottlenecks of food availability. Rather than searching and/or finding the perfect crop to substitute for tobacco, farmers together with researchers assessed pathways to identify a gradual, dynamic and innovative transition focusing on the start and end of the (tobacco) season and "therefore providing a transitional stream of income" [63] (p. 165). Still a legal crop, courts rule to limit the amount of land under tobacco, and the crop is found to have little in common with cash crops that are welcomed and recognized as contributing positively to society (e.g., vegetables, spices, oil seeds, jute). Costs (to access markets, seed, transportation, etc.) together with complex land leasing/contractual arrangements indicate that there is no one-sizefits-all approach [63]. A full exit from tobacco is seen to enhance food security that is a paramount national imperative. Nationally, on most land under tobacco up to three crops can be cultivated per season in mixed farming. Thus, tests of economic viability confirmed that considerable economic rates of return on financial inputs, labour and land are available to farmers who start to phase out tobacco. Since they were put into a position to acquire relevant knowledge and gain access to seeds and markets, it came with no surprise that none of the hundreds of farmers in the experiment has returned to tobacco growing [63].

- Differently, the Government of Kenya, also a Party to the FCTC, passed legislation to regulate production, but the practice of holding shares of the tobacco industry turned out to be counterproductive when directly searching for alternative developments, "making the government complicit in the industry's current expansion within the country" [49] (p. 194). From 2006 to 2009, state-supported experiments were carried out by civil society organizations with bamboo cultivation, testing the engagement of hundreds of farmers in the South Nyanza Region in substituting tobacco for bamboo, a multi-purpose agro-forestry crop. Bamboo Farmers' Cooperatives were set up for marketing, processing and training (poles, furniture and handicrafts, mainly) [49]. A comparison between tobacco and bamboo revealed that income generated by bamboo farming has been up to five times higher than that achieved by tobacco. In addition, when farmers cultivated peppers and other vegetables during the first year together with bamboo (expecting bamboo to reach maturity after three years), they experienced extra sources of income due to intercropping. Except for one district, nearly $75 \%$ of the farmers with the tobacco transition experiments phased out $N$. tabacum, albeit the industry has not stopped its activities in the area, mainly due to contractual arrangements between individual growers and TNCs such as BAT [49]. 
- In Brazil, FCV has turned the country into a highly prominent, export-oriented producer for the international market, with the Rio Pardo Valley in the south generating $97 \%$ of national production [64]. As a party to the FCTC, the Brazilian government implemented a National Programme for Diversification in Tobacco-Growing Areas that provided assistance through rural extension services to open up chances of employment and revenues, especially for family agriculture. As a compromise, and reflecting the situation where smallholders find themselves embedded in contracts with TNCs such as BAT, the programme explicitly states that it will not prohibit tobacco production. Overall, "governance of the process is extremely confused, making it difficult to enforce policy changes in a meaningful way", mainly because transformative action on diversification cannot be integrated into the inherited, national institutional setting of the country [64] (p. 231).

In sum, a generalization of national, evidence-based case study material suggests that crops (or crop combinations) as well as strategies to diversify farming (or livelihoods) exist in the form of exit options for tobacco growing households. However, in the case of lacking support for smallholder agriculture and rural development in general (mainly due to macroeconomic policies), farmers have limited choices for a self-determined transition away from $N$. tabacum since extension services and market infrastructure are provided by the tobacco industry [65]. In order to make use of synergies in adjustments of tobacco curing technology (see Section 3.2.1), the objective cannot be to phase out tobacco production suddenly but move gradually towards a transition in which alternative livelihoods and perhaps even naturally cured tobaccos still play a role in ecologically sound land-use decision making. Foreseeably, supply-side tobacco-control interventions will not negatively impact upon the existing generation of tobacco growers. Instead, they will realize willingness and practical actions of the state (access to public financing, continued withdrawal of tobacco subsidies) to assist them in a transition to tobacco-free livelihoods and alternative crops. However, it appears that rather than "a national vision for sustainable agriculture" a truly planetary vision is needed as key to overcome the negative (and interlinked) effects of environmental change and agricultural land use, epitomized, among others, in tobacco-attributable deforestation [65] (p. 253). In this context, and again trying to enact multiple synergies to overcome the land-use trilemma, a sustainability transition needs to be guided by the principles of agro-ecology as an "antithesis of industrial agriculture" (such as tobacco farming) [3] (p. 362), i.e., linking local and traditional knowledge with scientific findings that aim to socio-ecologically transform global agricultural supply chains of the agro-food system. A focus will be essential on small-scale, diversified farming systems that can optimize nutrient cycles boosting ecosystem services and, thus, resilience $[66,67]$.

\subsection{Digital Land Monitoring and Transformative Governance}

Tobacco land stewardship and governance require monitoring that helps to document the properties of biodiversity and land (or soils) in an effort to make use of multiple benefits $[3,68]$. Since digitalized spatial datasets and digitally supported monitoring are increasingly used for implementing land-use decision making, the ESATG-driven mapping and monitoring efforts concerning tobacco-attributable deforestation (cf. Table 2) and alternative land uses (cf. Section 3.2.3) should likewise follow this format. In addition, and apart from satellites, material infrastructure needs to be installed on Earth. Most evident from so-called REDD+ activities, i.e., the forest conservation and reforestation programme under UNFCC, digitalization lays ground for the continuous evaluation of data, making possible a novel way of monitoring alternative land uses from design/research to experiment/application in situ [69]. Most valuable contributions stem from digitally supported monitoring systems combined with RS and locally based sensors such as GPS trackers and smartphones. The latter might be useful not only in state-driven tobacco mapping/monitoring activities, but also for stakeholder applications when local farming population, civil society organizations and/or citizen science (CS) networking platforms plan to improve the quality of research-generated data and information about local proper- 
ties, thus increasing awareness with regard to sustainability and the SDGs [70]. Reflecting the IDRC cases of tobacco livelihood diversification in the light of ecosystem service management $[49,63-65]$, it can be inferred that CS may constitute a productive resource. Moving beyond digital methods, it allows to benefit from different knowledge systems that can be addressed with qualitative social research and mixed method approaches. There is reason to assume that monitoring land change dynamics will be available in due time internationally, striving for a consolidated and comprehensive perspective on CS and SDG indicators.

Several promising devices (concepts, tools, measures) exist to support the move towards consolidated tobacco land-use sustainability metrics [3]. For example, the Copernicus Land Monitoring Service (CLMS) generates products with relevance for LDN in the field of satellite-based RS and in situ data since 2012. CLMS's main components include efforts to map and thus identify various classes of land-use/cover (e.g., woodland or forest cover). Further, they are designed to survey changes (energy flows) of water and vegetation applying systematized (biophysical) parameters in a long-term time approach. With relevance for CS, the European operators (land.copernicus.eu) provide free and open access to information [3]. Likewise, satellite data such as Sentinel-2A imagery may also be evaluated for a wide variety of ESATG-related monitoring applications, including the analysis of soil degradation on tobacco plots and/or the cartographic classification of different land uses, be this tobacco growing, tobacco-attributable deforested area or land suitable for alternative crops [71]. In dry tropical forests such as the Miombo ecoregion, for example, RS-based research explored gains and losses in woodland cover in the Tabora Region, the leading FCV growing area of Tanzania (cf. Table 1). Given difficulties there to provide quantifications at the level of sub-districts, RS-based characteristics were field-validated and checked against land surface elements in the period 1990-2010, combining Landsat 5-8 data with a linear spectral mixture approach [23]. The land change detection method helped to monitor regional forest-cover changes and to identify local pathways of land change, thus improving both insights into driving forces and measures of forest conservation. In Tabora, aggregate forest changes were found to outweigh national aggregate changes by factor 2, and net forest losses were found to be similar to previous RS work (i.e., about 10\%) [16], thus confirming a tropical dryland ecoregion at risk due to tobacco farming (cf. Table 1). This study by Marc Mayes and colleagues shows that satellite-based analysis can identify both drivers and pressures, making the point that both need to be estimated/evaluated with regard to forthcoming tobacco land changes [23].

Two points about the transformative, supply-side governance of tobacco need to be addressed explicitly. First, be it sustainable land stewardship or biodiversity, monitoring progress with digitalized spatial data can only be achieved incrementally, and second, implementation is more than a technical matter since it involves setting land-use policy priorities [3]. In this context, it is crucial to recall the failure of tobacco companies to self-report ecologically sound agricultural and forestry practices (including curing) in a transparent and trustworthy manner, as noted by TEEB [30,31]. Still, the tobacco industry's efforts are designed "to obfuscate the environmental impact of its business", and "a fundamental and irreconcilable conflict between the tobacco industry's interests and public health policy interests", including supply-side tobacco regulation, continues to exist [1] (p. 34). For this reason, the industry and its associate partners (or front groups) have been made eligible under FCTC Article 5.3 (General obligations) that requires Parties to the FCTC "to exclude the tobacco industry from participating in decision-making, management and other activities regarding the regulation of the environmental impact of their production processes. Stronger application of this Article would push tobacco companies to be more explicit in their sustainability reporting about the life cycle of tobacco products, given that they currently tend to use opaque, unclear and imprecise language" [1] (p. 32). Likewise, Article 13 (Tobacco advertising, promotion and sponsorship) sets out "to ban or restrict false CSR activities by the tobacco industry such as promoting re-forestation (...) in tobacco growing (...). The tobacco industry's poor (...) environmental stewardship 
record should also be more heavily publicized. These efforts should be linked to efforts under Article 5.3" [1] (p. 32). This implies that-rather than using CSR as greenwashingprinciples of ecological and economic responsibility need to be put into practice such as minimum taxation of global business activities, extended producer responsibility and/or product stewardship with relevance for concerns of land stewardship [1]. In sum, and "because tobacco companies regularly exploit the differences in national regulations to avoid declaring or paying for the environmental damage caused by their activities" [1] (p. 32), international treaties rather than national programmes and/or public-private partnerships (involving tobacco TNCs) will need to form a key element of any approach to achieve a sustainability transition in tobacco land use.

Numerous conventions, institutions and international organizations are working on the transformation of land use and land cover at the global scale. As suggested by the WBGU, a focus on co-operations under the Rio Conventions (CBD, UNCCD, UNFCCC), on scientific appraisals of land use [9-11,45,56] and on the potential for increasingly interlinkage (networking) is valid for enhancing tobacco land change [3]. Land stewardship, in particular, is already a central part of all three Rio conventions, with UNCCD aiming at land-degradation prevention and LDN, CBD at conserving and sustainably using land and land-related biodiversity, and UNFCCC addressing sinks and sources of GHG emissions from land together with climate change impacts on agriculture. Thus, socio-ecologically sound land management can be achieved if activities directed towards land stewardship are mainstreamed and jointly put into practice using synergies from all conventions (including FCTC) in a systematized and overarching effort [3]. In this regard, tobacco as the most widely cultivated and highly controversial crop is crucial to be integrated into a global architecture of land stewardship responsibility under the umbrella of the Rio conventions, supported by inclusion in the agenda of GLP (glp.earth) and/or the Global Landscapes Forum (GLF), for example. Concerning a global landscape approach, the mandate of GLF would need to be further developed then [72]. Likewise, global land use modelling initiatives and state rural extension services should be combined with CS initiatives in an effort to create transformation hubs (or competence centres) at the regional or landscape level, incorporating consistent references to the crises of agro-food, biodiversity and climate as transformative challenges. This will help researching and testing integrative, landscape-level land-use applications to transform into practice [3]. While existing forums of global tobacco land change such as IDRC are valuable, they would perhaps need to be refocused from a national level (stressing rural development) to a planetary/biosphere level (stressing land stewardship), and, additionally, be remodelled so as to become part of much larger co-operative alliances. Taking up a recommendation of the WBGU, it is useful to establish regional co-operations for cross-border implementation by like-minded states and subnational regions aside with supranational institutions framing global (rather than national) land-use transformations [3]. Given the wide distribution of tobacco growing activities across the globe, a focus on a few clusters (where tobacco farming is spatially concentrated) is an efficient way to find an entry point to supranational tobacco landscape alliances (two thirds of the world's tobacco land is concentrated in just five countries, i.e., China, Brazil, India, Indonesia and Malawi, with the latter situated in the Miombo ecoregion). Rather than continuing to follow an evidence-based focus on, for example, how to achieve transformation in minor tobacco growing countries such as in Europe [51,73], five tobacco clusters in the global south should become a central part of thinking about land stewardship and transformative governance.

In addition, and in order to generate attention and resources to the issues addressed in FCTC Articles 17 and 18, a global vision for sustainable tobacco land stewardship should become part of a "joint Conference of the Parties to the three Rio Conventions: the Global Land Summit" in 2025 [3] (p. 265). Therefore, the ESATG group needs to liaise with JLG between the secretariats of the UNFCCC, CBD and UNCCD that was established in 2001 to focus on how land-related challenges can be dealt with effectively. In general, the development of joint standards for safeguards to mainstream devices, tools, 
etc. and to promote uniform standards for e.g., environmental impact assessments across all conventions (including FCTC) constitutes an important venue to improve institutional co-operation and co-ordination at the international level [3]. Linking to JLG, organizing tobacco input into the agenda of a global land change conference and forming future landscape alliances requires the ESATG process to shift from a predominantly public health-driven to a distinctly land health-oriented activity. Therefore, already existing and land-related indicator systems concerning biomass use, biodiversity, etc., need to be screened, strengthened and supplemented with a view upon transparent monitoring through (shared) open data, perhaps involving CS. In order to arrive at much-improved land-use sustainability metrics for tobacco, the multiple-benefit strategies as outlined previously offer valuable starting points for important changes in terrestrial ecosystems and their services.

\section{Conclusions}

Since its implementation in 2007, the global regulation of tobacco as an agricultural crop has not received political (and public) attention, developing instead a "reactive and defensive stance" [65] (p. 248). This paper, mainly relating to deforestation, argues that the blockade is due both to industry greenwashing and a positivist, evidence-based approach used by WHO. The latter is driven by rational principles/guidelines and uses a linear, nonsystemic policy design (situation analysis $>$ process $>$ outcome) with a single supply-side indicator of environmental sustainability (reduce the number of trees lost while farming/curing), i.e., mimicking the demand-side indicator of public health (reduce the number of smokers). Such design for regulatory land-use policies was doomed to fail since it did not recognize and acknowledge the multiplicity of social, cultural, ecological, historical and political factors that have profound effects on land change, rural livelihoods and how land is used. Furthermore, no consolidated and agreed upon land-use sustainability metrics have ever been made available to assess, monitor and quantify the global tobacco land-use transition. Instead, a wide array of models, concepts, tools, devices and indicators had been applied addressing biodiversity and ecosystem impacts in an unrelated, theoretically untidy manner. Only with the emergence of planetary land change science, an orientation towards SDGs and the adoption of integrative landscape thinking, it is possible now to induce a sustainability transition in the face of the interlinked climate, biodiversity and agro-food crises [3]. This new approach will imply getting focused on multiple-benefit strategies including tobacco as a crop (ecosystem restoration, curing technology, SLM measures, etc.). The tobacco transition will need to be researched and designed involving a multiplicity of stakeholders, but with no direct contributions or interferences from the side of tobacco TNCs, given their obfuscating behaviour in addressing land stewardship along their agricultural supply chains in the past (given FCTC Articles 5.3 and 13). Support from digital technologies and usage of land surface monitoring systems to mainstream a selected, extended set of indicators is meaningful, but would need to be tested first, perhaps as a flagship activity to demonstrate its potential validity for a much wider landuse sustainability transition. Global rather than national co-operation is required and "existing international processes should ... be more closely coordinated at a Global Land Summit" showcasing tobacco among other land uses [3] (p. 229). However, it is evident from the ESATG process and other, if not most land-based sustainability initiatives that-if involvement and participation of local farming households and breaking the dependency on powerful tobacco TNCs cannot be achieved-(re)thinking and (re)designing tobacco land use tends to play out as a "science-driven, policy-oriented, bureaucracy centred project of environmental management" [74], merely (p. 279).

Funding: This review was funded by the British Ecological Society under its Ecology into Policy grant number $2287 / 2838$.

Institutional Review Board Statement: Not applicable.

Informed Consent Statement: Not applicable. 
Conflicts of Interest: The author declares no conflict of interest. The funder had no role in the design of the study; in the collection, analyses, or interpretation of data; in the writing of the manuscript, or in the decision to publish the results.

\section{References}

1. WHO. Tobacco and Its Environmental Impact: An Overview. Available online: https://apps.who.int/iris/bitstream/handle/10 665/255574/9789241512497-eng.pdf?sequence=1 (accessed on 29 June 2021).

2. WHO. Framework Convention on Tobacco Control. Available online: https://www.who.int/fctc/text_download/en/ (accessed on 28 June 2021).

3. WBGU. Rethinking Land in the Anthropocene: From Separation to Integration. Available online: https://www.wbgu.de/en/ publications/publication/landshift (accessed on 30 June 2021).

4. Clay, J. World Agriculture and the Environment: A Commodity-by-Commodity Guide to Impacts and Practices; Island Press: Washington, DC, USA, 2004; pp. 347-366.

5. Geist, H.J.; Schulze, A. Global Tobacco and the Regulation of Demand over the Substance. J. Health Dev. $2007,3,57-77$.

6. The Tobacco Atlas. Available online: https://tobaccoatlas.org/wp-content/uploads/2018/03/TobaccoAtlas_6thEdition_LoRes_ Rev0318.pdf (accessed on 30 June 2021).

7. Otañez, M.; Glantz, S.A. Social Responsibility in Tobacco Production? Tobacco Companies' Use of Green Supply Chains to Obscure the Real Costs of Tobacco Farming. Tob. Control. 2011, 20, 403-411. [CrossRef] [PubMed]

8. Lee, K.; Botero, N.C.; Novotny, T. 'Manage and Mitigate Punitive Regulatory Measures, Enhance the Corporate Image, Influence Public Policy': Industry Efforts to Shape Understanding of Tobacco-Attributable Deforestation. Glob. Health 2016, 12, 55. [CrossRef] [PubMed]

9. Sampson, R.N.; Bystriakova, N.; Brown, S.; Gonzalez, P.; Irland, L.C.; Kauppi, P.; Sedjo, R.; Thompson, I.D.; Barber, C.V.; Offrell, R. Timber, Fuel, and Fibre. In Ecosystems and Human Well-Being: Current State and Trends; Hassan, R., Scholes, R., Ash, N., Eds.; Island Press: Washington, DC, USA, 2005; Volume 1, pp. 243-269.

10. MEA. Cultivated Systems. Available online: https://millenniumassessment.org/documents/document.295.aspx.pdf (accessed on 28 June 2021).

11. Kasperson, R.E.; Dow, K.; Archer, E.R.M.; Cáceres, D.; Downing, T.E.; Elmqvist, T.; Eriksen, S.; Folke, C.; Han, G.; Iyengar, K.; et al. Vulnerable People and Places. In Ecosystems and Human Well-Being: Current State and Trends; Hassan, R., Scholes, R., Ash, N., Eds.; Island Press: Washington, DC, USA, 2005; Volume 1, pp. 143-164.

12. WHO; FCTC. Study Group on Economically Sustainable Alternatives to Tobacco Growing (in Relation to Articles 17 and 18 of the Convention). Available online: https:/ / apps.who.int/gb/fctc/PDF/cop3/FCTC_COP3_11-en.pdf (accessed on 28 June 2021).

13. Mangora, M.M. Ecological Impact of Tobacco Farming in Miombo Woodlands of Urambo District, Tanzania. Afr. J. Ecol. 2005, 43, 385-391. [CrossRef]

14. FAO. Global Forest Resources Assessment 2005. Available online: http://www.fao.org/3/a0400e/a0400e00.htm (accessed on 28 June 2021).

15. Abdallah, J.M.; Mbilinyi, B.; Ngaga, Y.N.; Ok'ting'ati, A. Impact of Flue-Cured Virginia on Miombo Woodland: A Case of Small-Scale Flue-Cured Virginia Production in Iringa Region, Tanzania. Discov. Innov. 2007, 19, 92-106. [CrossRef]

16. Yanda, P.Z. Impact of Small Scale Tobacco Growing on the Spatial and Temporal Distribution of Miombo Woodlands in Western Tanzania. J. Ecol. Nat. Environ. 2010, 2, 10-16. [CrossRef]

17. Jew, E.K.K.; Dougill, A.J.; Sallu, S.M. Tobacco Cultivation as a Driver of Land Use Changes and Degradation in the Miombo Woodlands of South-West Tanzania. Land Degrad. Develop. 2017, 28, 2636-2645. [CrossRef]

18. Fraser, A.I. The Use of Wood by the Tobacco Industry and the Ecological Implications; International Forest Science Consultancy: Edinburgh, UK, 1986.

19. International Tobacco Growers' Association. Submission to the Public Hearing on Agricultural Diversification and Crop Alterna-Tives to Tobacco for the WHO FCTC; ITGA: Castelo Branco, Portugal, 2007.

20. Kägi, W.; Schmid, M. Tobacco and Forests: The Role of the Tobacco Industry Regarding Deforestation, Afforestation and Reforestation; B.S.S. Economic Consultants Ltd.: Basel, Switzerland, 2010.

21. Munslow, B.; Katerere, Y.; Ferf, A.; O'Keefe, P. The Fuelwood Trap: A Study of the SADC Region; Earthscan: London, UK, 1988.

22. Moyo, S.; O'Keefe, P.; Sillm, M. The Southern African Environment: Profiles of the SADC Countries; Earthscan: London, UK, 1993.

23. Mayes, M.T.; Mustard, J.F.; Melillo, J.M. Forest Cover Change in Miombo Woodlands: Modeling Land Cover of African Dry Tropical Forests with Linear Spectral Mixture Analysis. Remote Sens. Environ. 2015, 165, 203-215. [CrossRef]

24. Syampungani, S.; Chirwa, P.W.; Akinnifesi, F.K.; Sileshi, G.; Ajayi, O.C. The Miombo Woodlands at the Cross Roads: Potential Threats, Sustainable Livelihoods, Policy Gaps and Challenges. Nat. Resour. Forum. 2009, 33, 150-159. [CrossRef]

25. Willcock, S.; Phillips, O.L.; Platts, P.J.; Swetnam, R.D.; Balmford, A.; Burgess, N.D.; Ahrends, A.; Bayliss, J.; Doggart, N.; Doody, K.; et al. Land Cover Change and Carbon Emissions over 100 Years in an African Biodiversity Hotspot. Glob. Chang. Biol. 2016, 22, 2787-2800. [CrossRef]

26. TEEB. The Economics of Ecosystems and Biodiversity in Business and Enterprise; Earthscan: London, UK, 2012.

27. CORESTA. Good Agricultural Practices (GAP) Guidelines. Available online: https://www.coresta.org/good-agriculturalpractices-gap-guidelines-29207.html (accessed on 29 June 2021). 
28. CORESTA. Sustainability in Leaf Tobacco Production. Available online: https://www.coresta.org/sustainability-leaf-tobaccoproduction-29948.html (accessed on 29 June 2021).

29. Stern, N. The Economics of Climate Change: The Stern Review; Cambridge University Press: Cambridge, UK, 2006.

30. Kallesoe, M.; Bertrand, N. Business Impacts and Dependence of Biodiversity and Ecosystem Services. In The Economics of Ecosystems and Biodiversity in Business and Enterprise; Bishop, J., Ed.; Earthscan: London, UK, 2012; pp. $27-81$.

31. Van der Lugt, C.; Gilbert, S.; Evison, W. Measuring and Reporting Biodiversity and Ecosystem Impacts and Dependence. In The Economics of Ecosystems and Biodiversity in Business and Enterprise; Bishop, J., Ed.; Earthscan: London, UK, 2012 ; pp. 83-127.

32. Pain, A.; Hancock, I.; Eden-Green, S.; Everett, B. Research and Evidence Collection on Issues Related to Articles 17 and 18 of the Framework Convention on Tobacco Control; DD International Ltd.: Corby, UK, 2012.

33. Geist, H.J.; Chang, K.; Etges, V.; Abdallah, J.M. Tobacco Growers at the Crossroads: Towards a Comparison of Diversification and Ecosystem Impacts. Land Use Policy 2009, 26, 1066-1079. [CrossRef]

34. WHO; FCTC. Economically Sustainable Alternatives to Tobacco Growing (in Relation to Articles 17 and 18 of the WHO Framework Convention on Tobacco Control). Available online: https://apps.who.int/gb/fctc/PDF/cop6/FCTC_COP6_12-en.pdf (accessed on 29 June 2021).

35. WHO; FCTC. Cigarette Smoking: An Assessment of Tobacco's Global Environmental Footprint Across its Entire Supply Chain, and Policy Strategies to Reduce It. Available online: https:/ / pubs.acs.org/doi/10.1021/acs.est.8b01533 (accessed on 29 June 2021).

36. WHO; FCTC. Decision: Economically Sustainable Alternatives to Tobacco Growing (in Relation to Articles 17 and 18 of the WHO Framework Convention on Tobacco Control). Available online: https://apps.who.int/gb/fctc/PDF/cop5/FCTC_COP5(8)-en. pdf?ua=1 (accessed on 29 June 2021).

37. WHO; FCTC. Decision: Implementation of Articles 17 and 18 (Alternative Livelihoods and Protection of the Environment). Available online: https:/ / www.who.int/fctc/cop/sessions/cop8/FCTC_COP8\%2819\%29.pdf (accessed on 29 June 2021 ).

38. Jacobs, R.; Gale, H.F.; Capehart, T.C.; Zhang, P.; Jha, P. The Supply-Side Effects of Tobacco Control Policies. In Tobacco Control in Developing Countries; Jha, P., Chaloupka, F.J., Eds.; Oxford University Press: New York, NY, USA, 2000; pp. 311-341.

39. UNCCD. Integration of the Sustainable Development Goals and Working Group Report on Land Degradation Neutrality. Available online: https://www.unccd.int/sites/default/files/sessions/documents/ICCD_COP12_4/4eng.pdf (accessed on 29 June 2021).

40. UN General Assembly. Transforming Our World: The 2030 Agenda for Sustainable Development. Available online: https://www. un.org/en/development/desa/population/migration/generalassembly/docs/globalcompact/A_RES_70_1_E.pdf (accessed on 29 June 2021).

41. Kulik, M.C.; Bialous, S.A.; Munthali, S.; Max, W. Tobacco Growing and the Sustainable Development Goals, Malawi. Bull. World Health Organ. 2017, 95, 362-367. [CrossRef] [PubMed]

42. Smith, P. Managing the Global Land Resource. Proc. Royal Soc. B 2018, 285, 1-9. [CrossRef] [PubMed]

43. Ellis, E.C.; Pascual, U.; Mertz, O. Ecosystem Services and Nature's Contribution to People: Negotiating Diverse Values and Trade-Offs in Land Systems. Curr. Opin. Environ. Sustain. 2019, 38, 86-94. [CrossRef]

44. Folke, C.; Österblom, H.; Jouffray, J.-B.; Lambin, E.F.; Adger, W.N.; Scheffler, M.; Crona, B.I.; Nyström, M.; Levin, S.A.; Carpenter, S.R.; et al. Transnational Corporations and the Challenge of Biosphere Stewardship. Nat. Ecol. Evol. 2019, 3, 1396-1403. [CrossRef] [PubMed]

45. IPCC. Climate Change and Land. Available online: https://www.ipcc.ch/site/assets/uploads/2019/08/Fullreport-1.pdf (accessed on 29 June 2021).

46. Gann, G.D.; McDonald, T.; Walder, B.; Aronson, J.; Nelson, C.R.; Jonson, J.; Hallett, J.G.; Eisenberg, C.; Guariguata, M.R.; Liu, J. International Principles and Standards for the Practice of Ecological Restoration. Restor. Ecol. 2019, 27, S1-S46. [CrossRef]

47. IUCN Global Standard for Nature-Based Solutions. Available online: https:/ /www.iucn.org/theme/nature-based-solutions/ resources / iucn-global-standard-nbs (accessed on 29 June 2021).

48. Sauer, J.; Abdallah, J.M. Forest Diversity, Tobacco Production and Resource Management in Tanzania. For. Policy Econ. 2007, 9 , 421-439. [CrossRef]

49. Kibwage, J.K.; Netondo, G.W.; Magati, P.O. Substituting Bamboo for Tobacco in South Nyanza Region, Kenya. In Tobacco Control and Tobacco Farming: Separating Myth from Reality; Leppan, W., Lecours, N., Buckles, D., Eds.; Anthem Press: London, UK, 2014; pp. 189-210.

50. Musoni, S.; Nazare, R.; Mazungu, E.; Chekenya, B. Redesign of Commonly Used Tobacco Curing Barns in Zimbabwe for Increased Energy Efficiency. Int. J. Eng. Sci. Technol. 2013, 5, 609-617.

51. Bortolini, M.; Gamberi, M.; Mora, C.; Regattieri, A. Greening the Tobacco Flue-Curing Process Using Biomass Energy: A Feasibility Study for the Flue-Cured Virginia Type in Italy. Int. J. Green Energy 2019, 16, 1220-1229. [CrossRef]

52. He, F.; Wei, F.; Ma, C.; Zhao, H.; Fan, Y.; Wang, L.; Wang, J.-A. Performance of an Intelligent Biomass Fuel Burner as an Alternative to Coal-Fired Heating for Tobacco Curing. Pol. J. Environ. Stud. 2021, 30, 131-140. [CrossRef]

53. Ngwira, S.; Watanabe, T. An Analysis of the Causes of Deforestation in Malawi: A Case of Mwazisi. Land 2019, 8, 48. [CrossRef]

54. Lawrence, M.; Tapiwa, K.A.; Lovemore, M.; Michael, M. Smallholder Tobacco Farmers and Forest Conservation in Mutasa District, Zimbabwe. Ecol. Evol. 2020, 5, 6-12. [CrossRef]

55. CORESTA. Best Practices and Crop Protection in Cigar Dark Air-Cured Tobacco. Available online: https://www.coresta.org/ best-practices-and-crop-protection-cigar-dark-air-cured-tobacco-30985.html (accessed on 29 June 2021). 
56. Montanarella, L.; Scholes, R.; Brainich, A. (Eds.) The IPBES Assessment Report on Land Degradation and Restoration. Secretariat of the Intergovernmental Science-Policy Platform on Biodiversity and Ecosystem Services: Bonn, Germany, 2018. [CrossRef]

57. Blicharska, M.; Smithers, R.J.; Mikusinski, G.; Rönnbäck, P.; Harrison, P.A.; Nilsson, M.; Sutherland, W.J. Biodiversity's Contributions to Sustainable Development. Nat. Sustain. 2019, 2, 1083-1093. [CrossRef]

58. Marques, A.; Martins, I.S.; Kastner, T.; Plutzar, C.; Theurl, M.C.; Eisenmenger, M.; Huijbregts, M.A.J.; Wood, R.; Stadler, K.; Bruckner, M.; et al. Increasing Impacts of Land Use on Biodiversity and Carbon Sequestration Driven by Population and Economic Growth. Nat. Ecol. Evol. 2019, 3, 628-637. [CrossRef] [PubMed]

59. FAO. The State of the World's Biodiversity for Food and Agriculture. Available online: http://www.fao.org/docume.nts/card/ en/c/ca3129en/ (accessed on 29 June 2021).

60. Krausmann, F.; Erb, K.H.; Gingrich, S.; Haberl, H.; Bondeau, A.; Gaube, V.; Lauk, C.; Plutzar, C.; Searchinger, T. Global Human Appropriation of Net Primary Production Doubled in the 20th Century. Proc. Natl. Acad. Sci. USA 2013, 110, 10324-10329. [CrossRef] [PubMed]

61. FAO. The State of Food Security and Nutrition in the World. 2020. Available online: http://www.fao.org/documents/card/en/ c/ca9692en/ (accessed on 29 June 2021).

62. Fang, J.; Lee, K.; Sejpal, N. The China National Tobacco Corporation: From Domestic to Global Dragon? Glob. Public Health 2017, 12, 315-334. [CrossRef]

63. Akhter, F.; Buckles, D.; Tito, R.H. Breaking the Dependency on Tobacco Production: Transition Strategies for Bangladesh In Tobacco Control and Tobacco Farming: Separating Myth from Reality; Leppan, W., Lecours, N., Buckles, D., Eds.; Anthem Press: London, UK, 2014; pp. 141-187.

64. De Almeida, G.E.G. Diversification Strategies for Tobacco Farmers: Lessons from Brazil. In Tobacco Control and Tobacco Farming: Separating Myth from Reality; Leppan, W., Lecours, N., Buckles, D., Eds.; Anthem Press: London, UK, 2014; pp. $211-245$.

65. Buckles, D.; Lecours, N.; Leppan, W. Reframing the Debate on Tobacco Control and Tobacco Farming. In Tobacco Control and Tobacco Farming: Separating Myth from Reality; Leppan, W., Lecours, N., Buckles, D., Eds.; Anthem Press: London, UK, 2014; pp. 247-270.

66. IAASTD. Agriculture at Crossroads: Global Report. Available online: https://wedocs.unep.org/handle/20.500.11822/8590 (accessed on 30 June 2021).

67. Zimmerer, K.S.; Eric, F.; Lambin, E.F.; Vanek, S.J. Smallholder Telecoupling and Potential Sustainability. Ecol. Soc. 2018, 23. [CrossRef]

68. Turner, W. Sensing Biodiversity. Science 2014, 346, 301-302. [CrossRef]

69. OECD. Towards Sustainable Land Use. Available online: https://www.oecd.org/environment/resources/towards-sustainableland-use-aligning-biodiversity-climate-and-food-policies.pdf (accessed on 30 June 2021).

70. Citizen Science Global Partnership. Available online: http:/ / citizenscienceglobal.org/ (accessed on 30 June 2021).

71. Preidl, S.; Lange, M.; Doktor, D. Introducing APiC for Regionalised Land Cover Mapping on the National Scale Using Sentinel-2A Imagery. Remote Sens. Environ. 2020, 240, 111673. [CrossRef]

72. Global Landscapes Forum. Connect-Share-Learn-Act. Available online: https://www.globallandscapesforum.org/ (accessed on 30 June 2021).

73. Kienle, U.; Manos, B.; Jungbluth, T. Alternatives to Tobacco Cultivation: Towards an Evidenc Based Approach. Land Use Policy 2015, 45, 199-203. [CrossRef]

74. Smith, N. Nature at the Millennium: Production and Re-enchantment. In Remaking Reality: Nature at the Millennium; Braun, B., Castree, N., Eds.; Routledge: New York, NY, USA, 1998; pp. 271-285. 